\title{
Investigation of the operation speed of AC voltage sensor
}

\author{
Vladimirs Cimanis, Vladimirs Hramcovs, Ivars Rankis \\ Riga Technical university (Riga,Latvia) \\ vladimirs.cimanis@,rtu.lv, vladimirs.hramcovs@,rtu.lv, rankis@eef.rtu.lv
}

\begin{abstract}
In the article the AC voltage sensor of industrial frequency - the signal former of the analogue controller with pulse-width modulation which, in its turn, controls the highfrequency electronic pulse AC voltage stabilizer, is considered.
\end{abstract}

\section{INTRODUCTION}

Regulation of the sinus shape AC voltage including its stabilization similarly as for DC voltage can be implemented applying a pulse regulator operating on the PWM principles $[1,2]$. But for stabilization system performing a good feedback voltage sensor must be applied producing DC signal proportional to the magnitude of the AC sinus shape voltage. At that to obtain a better stabilization the feed-back signal must follow the $\mathrm{AC}$ voltage changing with extreme processing speed.

Operation principles of such sensor can be different but in all cases the checked voltage is applied in form of the two-wave unidirectional voltage in output of rectifier [3]. Solution based on integrating $\mathrm{RC}$-circuit is popular counting voltage across capacitor plates at the end of each wave. If diode is inserted in circuit of RC a DC voltage proportional to the magnitude of the sinus shaped AC voltage but only if time constant of circuit is much smaller as length of half-cycle of voltage considered. However after fixing the level of signal capacitor must be discharged for proper considering of the next half-cycle. It's possible to apply for the goal as analogue (on base of OP) as also digital (ADC/DAC) integrating devices.

However in all presented realization cases input signal of sensor is obtained in sequence of discreet levels links of unipolar voltages. Obviously duration of each link is equal to the half-cycle of voltage measured. As result such a feed-back signal has a stepwise changes but that is drawback for control of analogue PWM possible to arise a self-oscillations in system. To eliminate them it's necessary complemented sensor with inertial link which reduce processing speed. At that all these improvements are difficult for realization.

Taking into account above mentioned in this paper is described another version of sensor with simplest construction and much higher processing speed. In essence capacitive link can be supplied with DC signal and high frequency AC ripple but such solution also in some extent reduces processing speed in dynamics. Relations between ripple size, their frequency and time constant $\tau$ of the smoothing filter at parallel connection of capacitor and resistor can be described as $[3,4]$ :

$$
\tau=\frac{\frac{2 \pi}{p}-\arccos \left(1-\frac{\Delta U_{\%}}{100}\right)}{\omega \cdot \ln \left(\frac{1}{1-\frac{\Delta U_{\%}}{100}}\right)},
$$

where $p$ is number of ripples in output voltage of diode rectifier scheme supplied with evaluated sinus shape AC with angular frequency $\omega$;

$$
\Delta U_{\%}=\left(\frac{U_{\max }-U_{\min }}{U_{\max }}\right) \cdot 100 \% \text { is relative ripple size of }
$$

rectifier's output voltage.

Expression (1) corresponds to filter capacitor discharging process from voltage $U_{\max }$ to $U_{\min }$.

On Fig. 1 is presented computer modelling scheme for sensor with two-wave rectifier. Here sensor is presented as voltagedown transformer with centre tap diode rectifier in secondary circuit. At primary voltage can be stepwise increased and decreased using for that supplementary transformer.

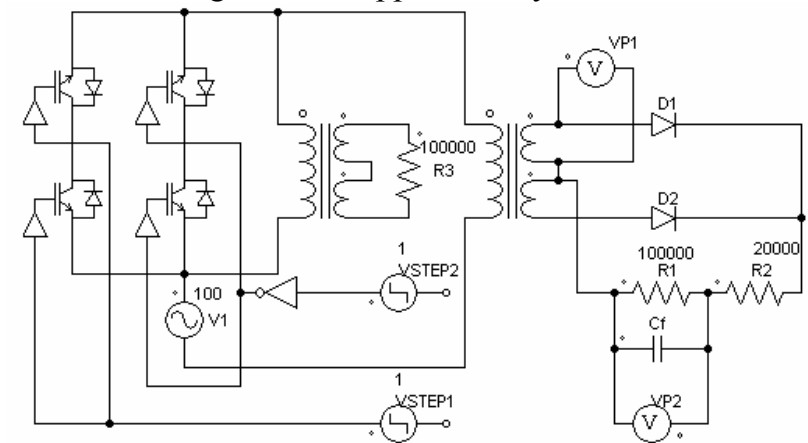

Fig.1. Scheme of computer modelling of sensor with two-wave rectifier

Parameters of $\mathrm{R}_{1}$ and $\mathrm{C}_{\mathrm{f}}$ (see Fig.1) are accepted in accordance with (1) at $\Delta \mathrm{U}_{\%}=5 \%$ in stationary case. From diagrams Fig.2a,b is seen that output signal VP2 in case of step-down of measured voltage is lagging by $9 \ldots 10$ cycles (Fig.2,a). 
Accepting at output larger capacitor providing $\Delta \mathrm{U}_{\%}=1 \%$, processing speed is more worse (Fig.2,b). It can be concluded that for rising of processing speed capacitance must be decreased but providing same relative ripple $\Delta \mathrm{U}_{\%}$ with multiplication of ripple number $p$ in cycle which corresponds to expression (1).

a)

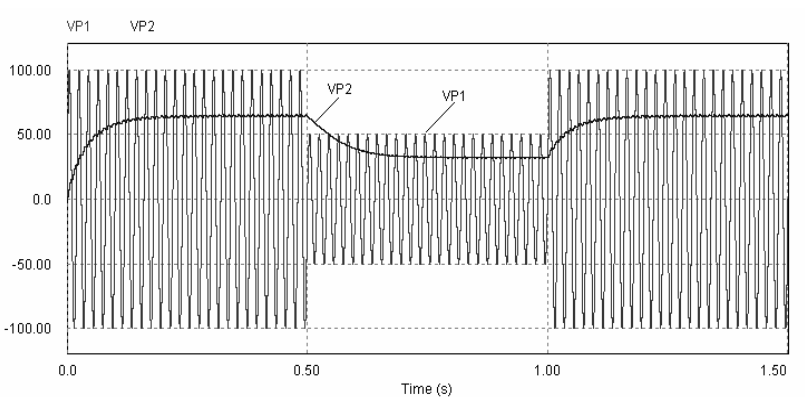

b)

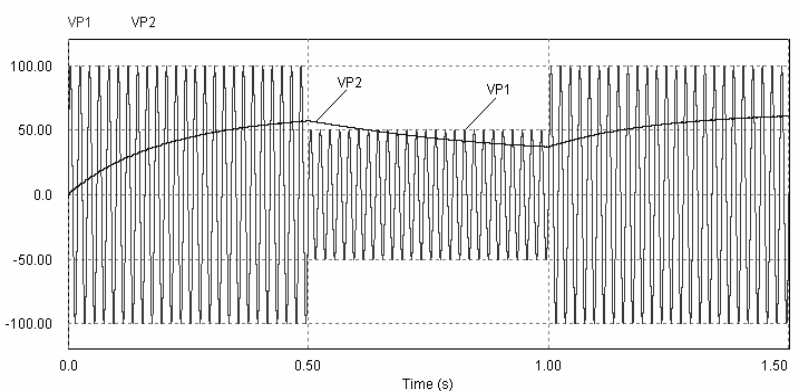

Fig.2. Investigation of sensor with two-wave rectifier in dynamics: a) dynamics response at step-down of input voltage and accepted $\Delta \mathrm{U}_{\%}=5 \%$; b) dynamic response at accepted $\Delta \mathrm{U}_{\%}=1 \%$.

\section{OPERATION PRINCIPLE OF THE SENSOR AND ITS CONSTRUCTION}

In Fig. 3 is presented a calculated time constants at $p=2,4,6$, 10,18 . As comment it must be said that at $p=10$ and $p=18$ ripple level $\Delta \mathrm{U}_{\%}=5 \%$ can be obtained without any filtering devices.

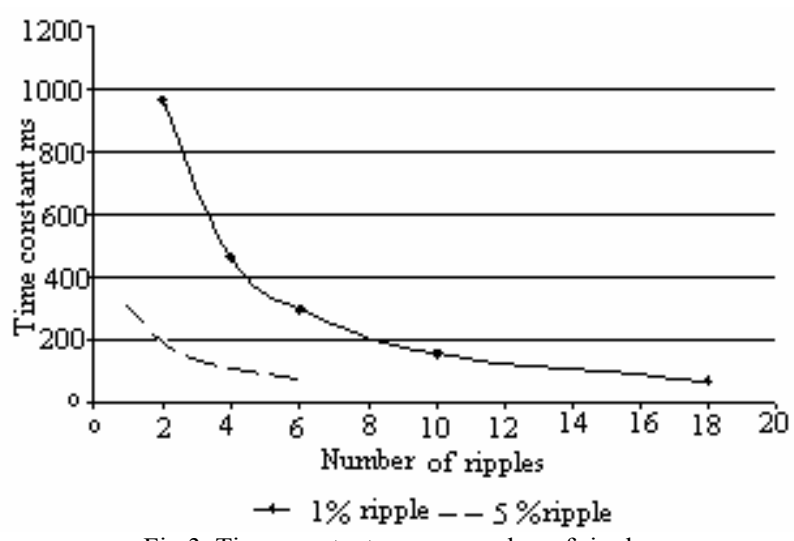

Fig.3. Time constant versus number of ripples

As it can be seen from Fig.3 processing speed can be improved essentially rising number of ripples up to 18 (in 20 times compare to two ripple case). Such rising of ripple number can be reached using multi-phase rectifying schemes: $\mathrm{p}=4$ can be reached in four-phase one-wave scheme;

$\mathrm{p}=6$ in three-phase bridge scheme;

$\mathrm{p}=10$ in five-phase bridge scheme;

$\mathrm{p}=18$ in nine-phase bridge scheme.

Artificial obtaining of small power multi-phase rectifying schemes is possible on base of symmetric multi-phase voltage which can be obtained from single-phase measured voltage using bridge mode phase shifting scheme (Fig.4).

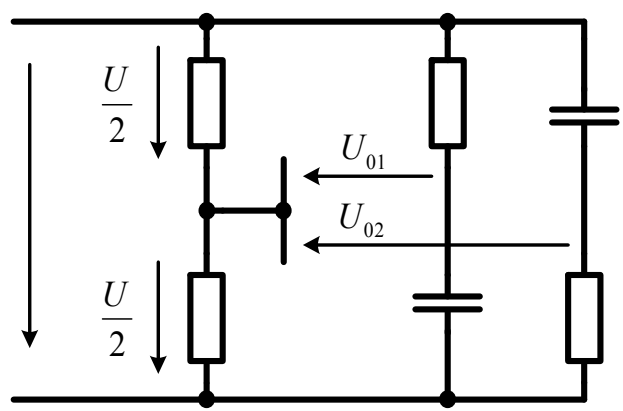

Fig.4. Scheme of bridge mode phase shifting device

When bridge is operating in no-load regime

and

$$
\begin{aligned}
& \dot{U}_{01}=\left(\frac{\dot{U}}{2}\right) \cdot e^{-j \psi_{1}} \\
& \dot{U}_{02}=\left(\frac{\dot{U}}{2}\right) \cdot e^{j \psi_{2}},
\end{aligned}
$$

where $\psi$ is phase shift of voltage $\mathrm{U}_{0}$ in respect to input voltage U. From vector diagrams for phase shifting bridge

$$
\begin{gathered}
\left|\psi_{1}\right|=\pi-2 \cdot\left|\varphi_{1}\right|, \text { where }\left|\varphi_{1}\right|=\operatorname{arctg} \frac{X_{c 1}}{R_{1}} ; \\
\psi_{2}=2 \cdot\left|\varphi_{2}\right|, \text { where }\left|\varphi_{2}\right|=\operatorname{arctg} \frac{X_{c 2}}{R_{2}} .
\end{gathered}
$$

Calculating by (4) a parameters of phase-shifting RC link in accordance with requested number of phases in symmetric voltage system, it's possible to obtain the multi-phase rectifiers for operation in sensor mode at no-load conditions [5]. As example on Fig. 5 is presented computer modelling scheme with according input VP1 and output VP2 voltage diagrams for five-phase bridge rectifier. Initial transient process can be observed in duration of one cycle and after it a stationary operation begins.

Considering processing speed of the presented five-phase rectifier a computer modelling at step-up and step-down input voltage leaps was elaborated (Fig.6). From Fig.6 we can see that output voltage follows to changes of input one with minimal delay. At that resistance of resistor R5 for considering a no-load condition was accepted as 


$$
R_{5} \gg R_{i}
$$

where $R_{i}$ is resistance of the phase-shifting links.

\section{LOADED OPERATION OF ELABORATED SENSOR}

As it was declared for simplification a no-load regime was accepted. Such assumption means that at really loading of sensor obtained simplified phase shifting angles should not be preserved. Therefore it's necessary to calculate sensor at some certain loading inside it which means that in hereafter.
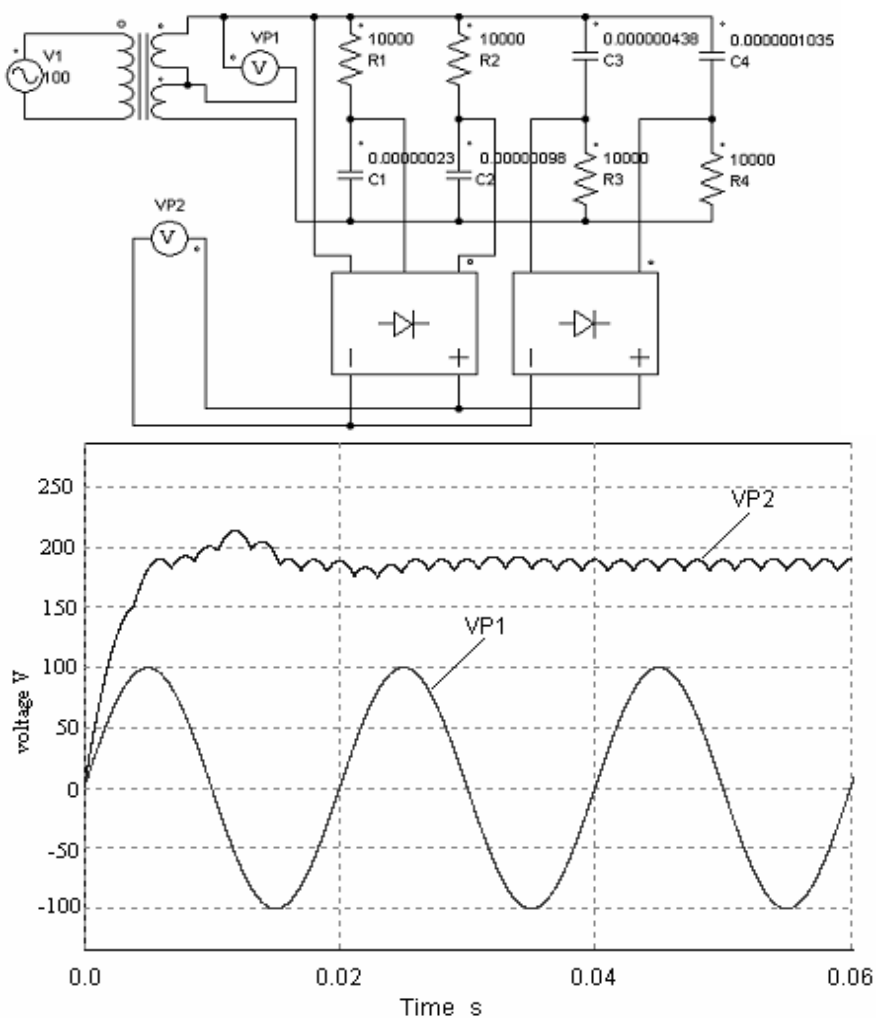

Fig.5. Modelling scheme of five-phase rectifier and input-output voltage diagrams

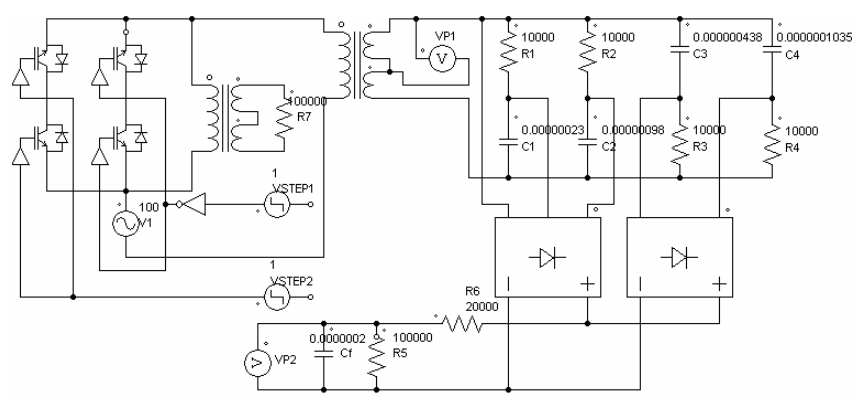

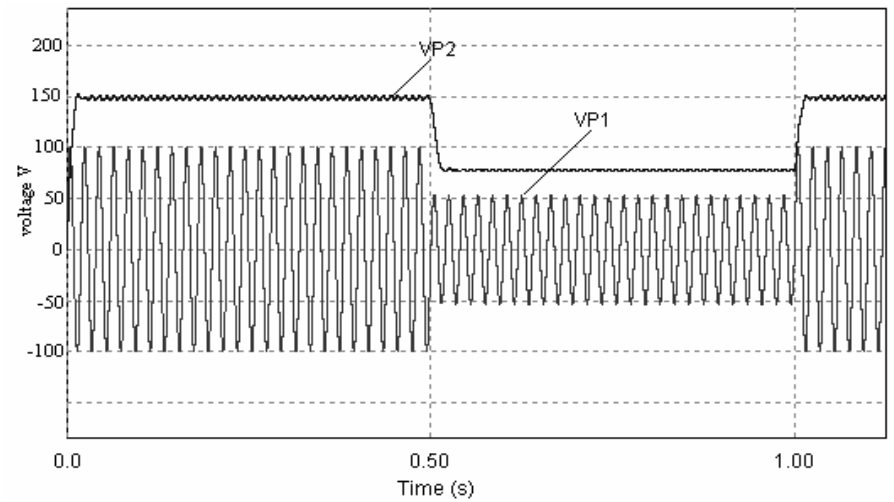

Fig.6. Modelling scheme of five-phase rectifier-sensor and output signal diagram at stepwise change in input voltage

Analysis of loaded artificial scheme of multi-phase voltage at loading is rather complex task. Simplest way is calculate parameters of phase-shifting bridge link (on base of given phase shifting angles), loading each link of shifted voltage with resistive load across diagonal of the bridge.

On Fig.7 is shown analysed scheme of phase-shifting junction with one phase-shifting RC link. Voltage measured is connected through voltage-down transformer the secondary winding of which is centre tapped.

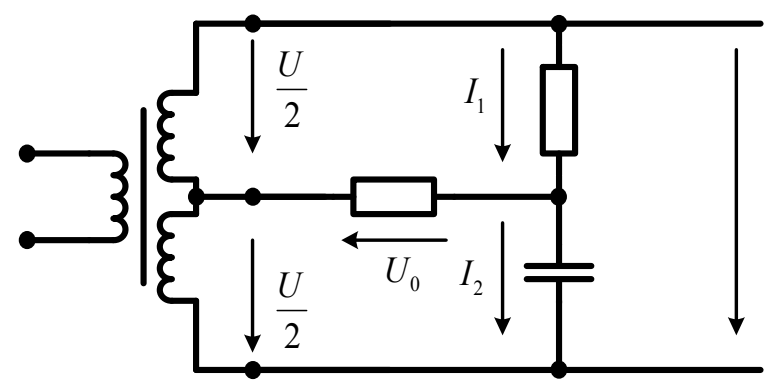

Fig.7. Calculation scheme of loaded phase-shifting link

Calculating the scheme applying Kirchhoff's Law with symbolic method we can obtain [6]

$$
\dot{U}=\frac{\frac{\dot{U}}{2}\left(R_{1} R_{0}+j R_{0} X_{c 1}\right)}{j X_{c 1}\left(R_{1}+R_{0}\right)-R_{1} R_{0}} .
$$

Converting in more convenient form without imaginary numbers in denominator

$$
\dot{U}_{0}=\frac{\dot{U}}{2} \cdot \frac{R_{0}{ }^{2}\left(X_{c 1}{ }^{2}-j 2 X_{c 1} R_{1}-R_{1}^{2}\right)+R_{0}\left(R_{1} X_{c 1}{ }^{2}-j R_{1}{ }^{2} X_{c 1}\right)}{\left(R_{1} R_{0}\right)^{2}+\left(R_{1} X_{c 1}+R_{0} X_{c 1}\right)^{2}}
$$

Accepting in (5) $\dot{U}=U$ where $U$ is a real number phase shifting angle $\psi$ of $\mathrm{U}_{0}$ in respect to the voltage $\mathrm{U}$ is

$$
\psi=\operatorname{arctg} \frac{\operatorname{Im}\left(\dot{U}_{0}\right)}{\operatorname{Re}\left(\dot{U}_{0}\right)} .
$$


It means that in accordance to the (6),(7) can be obtained necessary parameters of multi-phase voltage system taking as basis necessary angles $\psi_{1}, \psi_{2}, \ldots$ so on. Multi-phase rectifier scheme with parameters chosen in accordance with above given equations and internal load is presented on Fig.8. For better equalization of shifted voltages $\mathrm{U}_{01}, \mathrm{U}_{02} \ldots \mathrm{so}$ on, in practical calculations can be proposed choice the resistance $R_{0}$ equal in all links and keep $R_{0}>z_{i}$,

where $z_{i}=\sqrt{R_{i}^{2}+X_{c i}^{2}}$; can be proposed also to keep $\mathrm{z}_{\mathrm{i}} \approx$ const for all links. But $R_{0}<<R_{F}$, where $\mathrm{R}_{\mathrm{F}}$ is probable load of multi-phase rectifier.

In such way obtained artificial voltage system voltages of links $\mathrm{U}_{01}, \mathrm{U}_{02} \ldots \mathrm{U}_{0 \mathrm{i}}$ will be proper shifted but also rather different by their magnitude (see Fig. 9,a). For their equalization a load resistors of links $\mathrm{R}_{0}$ can be realized as voltage dividers taking to rectifier symmetric multi-phase voltages (see scheme 8 and diagram Fig.9,b). On Fig.9,c is shown obtained output DC signal VP7 connected with measured voltageVP1.

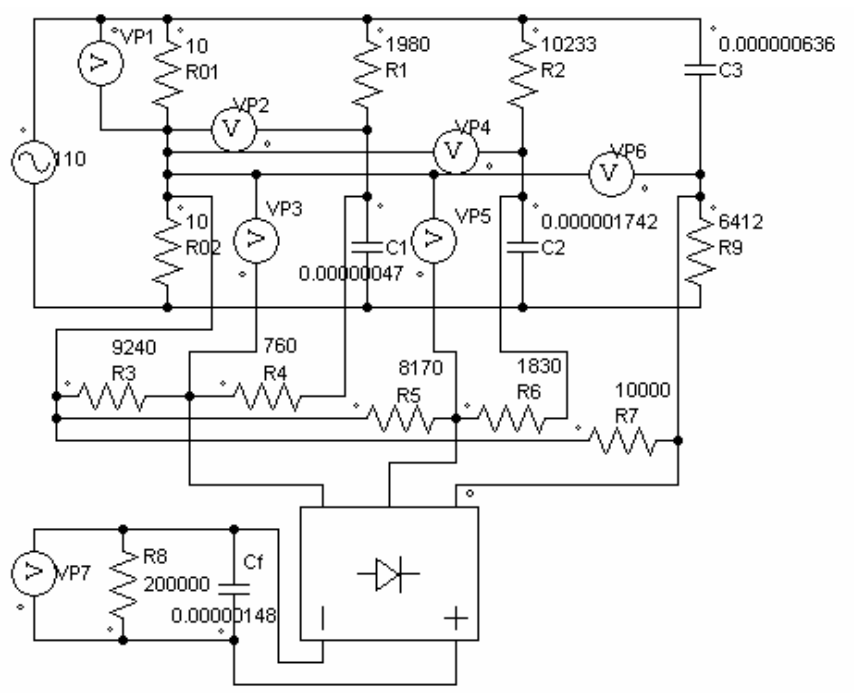

Fig.8. Scheme of multi-phase sensor with internal load

For better equalization of rectifiers input voltages the internal load resistors were realized as voltage dividers with different nominal (see. Fig.8). Above described scheme with inside loading was investigated also in dynamics (Fig.9).

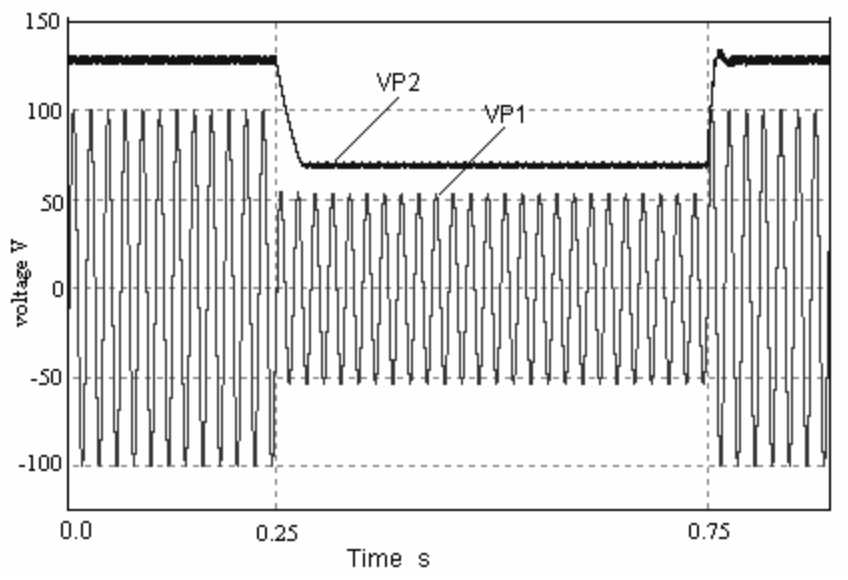

Fig.9. Investigation of the scheme in dynamics

Dynamic response at step-drop of input voltage lasts some two periods of input voltage. At step rising of input voltage response is much faster - less as one cycle time. Optimizting an output filters of rectifier it's possible to get more faster processing at smaller ripple range in stationary operation case.

At the end it must be complemented as optimal number of phase for rectifier also is subject of improvement of the scheme.

\section{CONCLUSIONS}

1. Applying of multi-phase rectifier is useful for obtaining a fast processing sensor for measurment of input sinus shape voltage's magnitude.

2. Obtaining of multi-phase symmetric voltage can be realized using phase-shifting RC bridges.

3. For lessening of sensor's external load influence i's preferable to install an internal load of RC phase-shifting links.

4. Optimization of number of phases as also realization mode of filters at output of sensor is optimization task actual for elaboration of sensor.

\section{REFERENCES}

[1] Greivulis J., Rankis I. Electronic Elements and Junctions of Equipment Control Systems - Riga: Avots,1997. - 287 pp.

Greivulis J., Raņkisis I. Iekārtu vadības elektroniskie elementi un mezgli.-Rīga: Avots, 1997.-287lpp.

[2] Latvian Patent $\mathrm{Nr} 13835$ Stabilizer of the Sinus Shape AC voltage/ V.Hramcovs, V.Cimanis, I.Rankis, 2009

Latvijas patents $\mathrm{Nr} 13835$ Sinusoidālā mainsprieguma stabilizators/ V.Hramcovs, V.Cīmanis, I.Raņķis, 2009

[3] L.Bobrovnikov Electronocs - SPB:Piter,2004.-560pp.

Л.Бобровников Электроника, СПб:Питер, 2004.-560 стр.

[4] Rankis I., Bunina I. Power Electronics - Riga:RTU, 2007. - 220 pp.

Rankis I. Energoelektronika - RTU Izdevniecība, 2007- 220 lpp.

[5] Latvian Patent Nr 13895 Measurement Sensor for Amplitude of Sinus Shape AC Voltage/ V.Hramcovs, V.Cimanis, I.Rankis, 2009

Latvijas patents $\mathrm{Nr} 13895$ Sinusoidāla mainssprieguma amplitūdas sensors/ V.Hramcovs, V.Cīmanis, I.Raņkisis, 2009

[6] Theoretical Bases of Electrical Engineering. Stationary Processes in Linear Circuits/ K.Tabaks and other. - Riga:Zvaigzne,1985. - 332 1pp.

Elektrotehnikas teorētiskie pamati. Stacionāri procesi lineārās ķēdēs / K.Tabaka red.-R.:Zvaigzne, 1985.-332 lpp. 
Cimanis V., Hramcovs V., Rankis I. Investigation of the operation speed of AC voltage sensor In the article the AC voltage sensor of industrial frequency - the signal former of the analogue controller with pulse-width modulation which, in its turn, controls the high-frequency electronic pulse AC voltage stabilizer, is considered. It is shown, that the necessary for controller feedback signal in the form of DC voltage can be received by means of the multiphase rectification scheme. The multiphase symmetrical voltage system is formed from a controlled single-phase voltage, using the phase-shifting bridge with several RC-circuits. Speed of such sensor depends on output circuit time lag, i.e., on a smoothing filter time constant. In steady-state modes a variable component of the output signal is governed with output filter condenser capacity and quantity of voltage pulsations on an rectifier schema's output during controlled voltage period as well. The more the number of pulsations for the period, the less is the capacity of the filter condenser, which limits sensor's speed with a controlled voltage change. In the work the dependence of a time constant on a quantity of pulsations of the rectified voltage with reference to $1 \%$ and $5 \%$ to pulsations at a output signal of the sensor is received. With help of computer simulation of the changes of voltage amplitude, sensor's processing speed in an idling mode is estimated. The calculation methods were developed for phase-shifting circuits during the work of a sensor with variable loading. As an example the results of tests of speed of the loaded sensor with threephase bridge rectifier scheme are also received.

\section{Cīmanis V., Hramcovs V., Rankisis I. Sinusoidālā sprieguma sensora ātrdarbības izpēte}

Rakstā tiek aplūkots rūpnieciskās frekvences sinusoidālā sprieguma sensors - signāla devējs impulsu platuma modulācijas analoga kontrollera vadīšanai, kas savukārt vada augstfrekvences impulsu regulēšanas mainsprieguma elektronisko stabilizatoru. Parādīts, ka kontrolleram nepieciešamais atgriezeniskās saites līdzsprieguma signāls ir iegūstams ar vairākfāžu taisngrieža palīdzību. Spriegumu daudzfāžu simetriskā sistēma tiek izveidota no kontrolējamā vienfāzes sprieguma, izmantojot fāzu griešanas tilta slēgumu ar vairākiem RC-posmiem. Tādā veidā sensora ātrdarbību nosaka izejas ķēdes inertums, t.i., kapacit̄̄vā gludinātājfiltra laika konstante. Stacionāros režīmos līdzsprieguma signāla relatīvo maiņkomponenti tieši nosaka kā gludinātājfiltra kondensatora kapacitāte, tā arī iztaisnotā sprieguma pulsāciju skaits kontrolējamā sprieguma perioda laikā. Jo vairāk ir pulsāciju periodā, jo mazāka var būt filtra kondensatora kapacitāte, kas savukārt, mainoties kontrolējamam spriegumam, ierobežo sensora ātrdarb̄̄bu. Darbā iegūta filtra laika konstantes sakarība ar taisngrieztā sprieguma pulsāciju skaitu periodā attiecināta uz sensora signāla $1 \%$ un $5 \%$ relat̄̄vām pulsācijām. Novērtēta dotā sensora ātrdarbība tukšgaitas režìmā, datormodelēšanā imitējot kontrolējamā sprieguma kritumus un uzmetienus. Izstrādāta fāzes nobīdīšanas posmu aprēķina metodika, fāzu griešanas tiltam (t.i., sensoram) strādājot slogotā režīmā. Pieņemot par paraugu mākslīgo trīsfāžu tilta taisngriešanas shēmu slogotajā sensorā, ar datormodelēšanas palīdzību veidojot pārejas procesus kontrolējamā sprieguma pusē, iegūti sensora ātrdarbības izmēginājumu rezultāti.

\section{Циманис В., Храмцов В., Ранькис И. Исследование быстродействия датчика синусоидального напряжения}

В статье рассмотрен датчик синусоидального напряжения промышленной частоть - формирователь сигнала для аналогового контроллера с широтно-импульсной модуляцией, который, в свою очередь, управляет высокочастотным электронным импульсным стабилизатором переменного напряжения. Показано, что необходимый для контроллера сигнал обратной связи в виде постоянного напряжения может быть получен с помощью многофазной схемьл выпрямления. Многофазная симметричная система напряжений образуется из контролируемого однофазного напряжения, используя фазовращательный мост с несколькими RC-звеньями. Быстродействие такого сенсора зависит от инериионности выходной цепи, т.е., от постоянной времени сглаживающего фильтра. В стационарных режимах переменную составляющую выходного сигнала обуславливает именно ёмкость конденсатора выходного фильтра, а также количество пульсаций напряжения на выходе выпрямительной схемы за период контролируемого напряжения. Чем больше число пульсаџий за период, тем меньше может быть ёмкость конденсатора фильтра, которая и ограничивает быстродействие датчика при изменениях контролируемого напряжения. В работе получена зависимость постоянной времени от числа пульсаций выпрямленного напряжения применительно к $1 \%$ и $5 \%$ пульсациям у выходного сигнала датчика. Имитируя компьютерным моделированием скачкообразные изменения контролируемого напряжения, оценено быстродействие датчика в режиме холостого хода. Разработана методика расчёта фазосдвигающих звеньев при работе датчика с варьируемой нагрузкой. В качестве примера получены также результаты испытаний быстродействия нагруженного датчика с 